\title{
The Impact of Crop Rotation and Nutrient Levels on Nutrition Quality, Yield and Yield Components of Maize (Zea maize L)
}

\author{
Mahama Salifu
}

\begin{abstract}
Institute of Crop Sciences, Faculty of Crop Production and Horticulture Science,University of Debrecen, H-4032 Debrecen,
\end{abstract} Böszörményi Str. 138, Salifumahama@agr.unideb.hu

\begin{abstract}
Cropping system in crop production has many advantages and ensures better crop growth and yielding. Crop rotation methods can show optimal plants densities for maximal photosynthetic efficiencies and plant growth. This study aimed at investigating the effects of different crop rotation systems: monoculture and biculture rotations, and different nitrogen levels on yield, yield components and grain nutrient quality.

The lowest Soil-Plant Analysis Development (SPAD), Leaf Area Index( LAI), Protein, plant height, cob length, and grain yield were found in monoculture plot signifying the influence of crop rotation on these measured variables.

Nitrogen level at $120 \mathrm{~kg} / \mathrm{ha}$ had a significant effect on Protein, plant height and grain yield on the monoculture field whiles Moisture content, Protein content number of rows per cob and grain yield were also significantly affected at 120kg/ha level of nitrogen application on the biculture plot
\end{abstract}

Keywords-Croprotation, maize, Nutrient quality, yield components.

\section{INTRODUCTION}

MAIZE (Zea mays L.) is a highly productive crop under optimal environmental and crop management conditions and it's a main grain crop world over, being used as a major staple food for both human consumption and as feed for animal. It has also become a major key resource for industrial applications and bioenergy production. It is a versatile crop and ranks third following wheat and rice in world production as reported by Food and Agriculture Organization [1].

Worldwide interest in long-term experiments has shown an increased in recent years, since suitable indicators of sustainable agriculture (yield trends, parameters characteristic of the quality of the ecosystem), are capable of serving as an early warning system, that can only be obtained in such experiments [2].

Crop rotation represents a way of approach in crop production research that enables the available natural resources to be preserved in a more efficient utilized ways. In crop rotation experiments, a monoculture is usually compared to various crop sequences. The fact that in most cases the yields of the cultivated crops are higher in crop rotation, as compared with a monoculture under identical conditions, is explained by the rotation effect. This rotation effect has been demonstrated irrespective of the combination of crops in the rotation system. [3] , [4], and [5].

The benefits of crop rotation for land and water resource protection and productivity have been identified, but many of the rotation factors, processes and mechanisms responsible for increased yield and other benefits need to be better understood. Increased nitrogen supply is sometimes responsible, but improvements in soil water availability, soil nutrient availability, soil structure, soil microbial activity and weed control, decreased insect pressure and disease incidence, and the presence of phytotoxic compounds and or growth-promoting substances originating from crop residues have also been identified as contributing factors [6].

Plant nutrients especially nitrogen is an important element for crop survival and its lost from the soil or crop system may cause environmental pollution. Nitrate ( $\mathrm{NO}_{3}^{-}$) pollutes ground and surface waters [6], ammonia $\left(\mathrm{NH}_{3}\right)$ when deposited to land increases soil acidification and $\mathrm{N}$ eutrophication [8] and nitrous oxide (N2O) contributes to global warmingand breakdown of stratospheric ozone [9].

The aim of the present paper is to evaluate the effect of various crop sequences and fertilization treatments on yield and yield components of maize and grain nutrition quality of maize of fully irrigated monocultures and biculture plots of land on a longtime experimental field.

\section{MATERIALS AND METHODS}

The experimental site for this research is located at Latokep Research Centre of the University of Debrecen in Hungary. The experimental site is about $15 \mathrm{~km}$ way from the city center of Debrecen with geographic coordinates of $47^{\circ} 33^{\prime}$ N, $21^{\circ} 27^{\prime}$ E. 
The experiment soil is flat, leveled, and has soil genetic properties belonging to the calcareous chernozem. The experiment was set up on a split-split-plot design in three replication. The research was set up based on a two-factorial parameters and these are the nutrition levels (control, $80 \mathrm{~kg}$ of Nitrogen and $120 \mathrm{~kg}$ of Nitrogen), and different cropping system treatment (Monoculture and Biculture) on a plot of land with plant density of $\left(72,500 / \mathrm{ha}^{-1}\right)$. The plots were fully-irrigated in the cropping system.

On the irrigated treatment, optimal water-supply of plants shall be reached by adjusting irrigated water amount to the local temperature and precipitation values for the cropping year 2017. At the end of the cropping year of 2017, the deviation in April, July and September was positive, thus the lack of precipitation in the other months was balanced and the total precipitation of the season was higher $379.9 \mathrm{~mm}$ than the 30-years average of 345.1.

The issues that were considered in this research included, the morphological and physiological parameters (SPAD, LAI, NDVI) as well as yield and components thus, Cob length, cob diameter, number of rows per cob, number of kernel per row, etc. The grain moisture content and nutritional content was also measured at harvest.

The results of data for this research were processed and statistically analyzed using software Microsoft Excel and SPSS for windows. The objective of this particular study was to examine the impact of different cropping systems, monoculture and biculture, for maize and wheat rotation on the yield and yield components of maize (Zea mays 1).

\section{RESULTS AND DISCISSION}

In this study, analysis of data indicate that cropping system has a significant effect on the Spad, LAI, Protein, plant height, cob length and crop yield. Table 1 and 2.

The maximum yield and protein of maize was achieved as a result of crop rotation system being applied as Biculture had $6178.877 \mathrm{kh} / \mathrm{ha}$ as against Monoculture $4041.042 \mathrm{~kg} /$ ha yield in this research and this study concedes with [5]. (Table2) Crop rotation provided higher yield as compared to monoculture because of the activities of residues remaining of the previous crop on the soil. [10], especially on lands where the system is already consolidated. A general impact of the cropping system reflected only on LAI, as shown in this study. The negative impact of cropping system on monoculture with significantly lowest yield and LAI was observed. (Table1) The influence of cropping systems on LAI had been also reported by [11].
Table.I: Effects of cropping system on grain nutrient quality and photosynthetic parameters

\begin{tabular}{|l|l|l|l|l|l|l|}
\hline $\begin{array}{l}\text { TREATME } \\
\text { NTS }\end{array}$ & $\begin{array}{l}\text { SPA } \\
\text { D }\end{array}$ & $\begin{array}{l}\text { ND } \\
\text { VI }\end{array}$ & LAI & $\begin{array}{l}\text { PROT } \\
\text { EIN }\end{array}$ & $\begin{array}{l}\text { STA } \\
\text { RCH }\end{array}$ & $\begin{array}{l}\text { MOIST } \\
\text { URE }\end{array}$ \\
\hline MONOCU & 50.9 & 75. & 2.8 & $8.52 *$ & 73.74 & 17.31 \\
LTURE & $3 * *$ & 69 & $9 * *$ & $*$ & 74.04 & 17.76 \\
BICULTU & 54.0 & 75. & 2.4 & 9.07 & 0.41 & 0.54 \\
RE & 9 & 87 & 7 & 0.27 & & \\
CV $(\%)$ & 1.80 & 1.7 & 0.2 & & & \\
& & 7 & 8 & & & \\
\hline
\end{tabular}

*Correlation is significant at 0.05 level, ** correlation is significant at 0.01 level

Table.II: Effect of cropping system on yield components of

\begin{tabular}{|l|l|l|l|l|l|}
\hline TREATMEN & PLAN & COB & COB & NO. & YIELD \\
TS & T & LENG & WEIG & OF & \\
& HEIG & HT & HT & RO & \\
& HT & & & WS & \\
& & & & CO & \\
& & & & B & \\
\hline MONOCUL & 238.0 & $18.36^{*}$ & 185.50 & 15.4 & 4041.0 \\
TURE & $9 * *$ & 19.59 & 231.35 & 1 & $42^{*}$ \\
BICULTUR & 247.4 & 1.01 & 22.87 & 15.9 & 6178.8 \\
E & 2 & & & 8 & 77 \\
CV (\%) & 5.71 & & & 1.30 & 0.002 \\
\hline
\end{tabular}

*Correlation is significant at 0.05 level, ** correlation is significant at 0.01 level

Different levels of Nitrogen supply to plant on both Monoculture and Biculture fields has a significant effect on maize grain nutrient quality and yield as shown in Table3 below.

High rate of nitrogen $(120 \mathrm{~kg} / \mathrm{ha})$ supply to crops has an influence on the protein quality of the grains and also the yield of the maize grains in both cropping systems.[12]Also reported that, nitrogen application increases plant height and protein content of maize grain.

Plant height in the monoculture was significantly affected at the rate of $120 \mathrm{~kg} /$ ha of nitrogen supply but difference was recorded in the biculture plot.(Table 3 ). The number of rows per cob was also influence by nutrient levels at $120 \mathrm{~kg} / \mathrm{ha}$ in biculture plot. The moisture and starch content measured at harvest was significantly by nitrogen levels at $80 \mathrm{~kg} / \mathrm{ha}$ and $120 \mathrm{~kg} / \mathrm{ha}$ for monoculture and biculture respectively as shown in Table3. 
Table.III: Effects of Nitrogen levels on grain nutrient quality, yield and yield components of maize

\begin{tabular}{|c|c|c|c|c|c|c|c|}
\hline $\begin{array}{l}\text { MONO } \\
\text { CULTU } \\
\text { RE }\end{array}$ & $\begin{array}{l}\text { MOI } \\
\text { STU } \\
\text { RE }\end{array}$ & $\begin{array}{l}\text { PRO } \\
\text { TEI } \\
\mathrm{N}\end{array}$ & $\begin{array}{l}\text { ST } \\
\text { AR } \\
\text { CH }\end{array}$ & $\begin{array}{l}\text { HEI } \\
\text { GH } \\
\mathrm{T}\end{array}$ & $\begin{array}{l}\mathrm{L} \\
\mathrm{A} \\
\mathrm{I}\end{array}$ & $\begin{array}{l}\text { NO. } \\
\text { RO } \\
\text { W/C } \\
\text { OB }\end{array}$ & $\begin{array}{l}\text { YIE } \\
\text { LD/ } \\
\text { KG }\end{array}$ \\
\hline $\begin{array}{l}\text { CONTR } \\
\text { OL }\end{array}$ & $\begin{array}{l}17.75 \\
*\end{array}$ & 7.92 & $\begin{array}{l}73.9 \\
0\end{array}$ & $\begin{array}{l}227 . \\
2\end{array}$ & $\begin{array}{l}2 . \\
66\end{array}$ & $\begin{array}{l}15.1 \\
1\end{array}$ & 5638 \\
\hline $\mathrm{N} 80 \mathrm{KG}$ & 16.95 & 8.08 & $\begin{array}{l}74.4 \\
7 *\end{array}$ & $\begin{array}{l}235 . \\
3\end{array}$ & $\begin{array}{l}2 . \\
95\end{array}$ & $\begin{array}{l}15.7 \\
7\end{array}$ & 6788 \\
\hline $\begin{array}{l}\text { N120K } \\
\text { G }\end{array}$ & 17.03 & $\begin{array}{l}9.57 \\
*\end{array}$ & $\begin{array}{l}73.4 \\
5\end{array}$ & $\begin{array}{l}251 . \\
8 *\end{array}$ & $\begin{array}{l}3 . \\
05\end{array}$ & $\begin{array}{l}15.3 \\
3\end{array}$ & $\begin{array}{l}9596 \\
*\end{array}$ \\
\hline $\begin{array}{l}\text { BICUL } \\
\text { TURE }\end{array}$ & & & & & & & \\
\hline $\begin{array}{l}\text { CONTR } \\
\text { OL }\end{array}$ & 17.07 & 8.32 & $\begin{array}{l}75.6 \\
5^{*}\end{array}$ & $\begin{array}{l}248 . \\
0\end{array}$ & $\begin{array}{l}2 . \\
96 \\
*\end{array}$ & $\begin{array}{l}15.3 \\
3\end{array}$ & $\begin{array}{l}9834 \\
2\end{array}$ \\
\hline N80KG & 17.70 & 9.12 & $\begin{array}{l}73.9 \\
8 \\
\end{array}$ & $\begin{array}{l}246 . \\
8 \\
\end{array}$ & $\begin{array}{l}2 . \\
24\end{array}$ & $\begin{array}{l}14.7 \\
7 \\
\end{array}$ & $\begin{array}{l}1056 \\
1 \\
\end{array}$ \\
\hline $\begin{array}{l}\text { N120K } \\
\text { G }\end{array}$ & $\begin{array}{l}18.50 \\
*\end{array}$ & $\begin{array}{l}9.78 \\
*\end{array}$ & $\begin{array}{l}73.4 \\
8\end{array}$ & $\begin{array}{l}247 . \\
5\end{array}$ & $\begin{array}{l}2 . \\
19\end{array}$ & $\begin{array}{l}17.8 \\
3 *\end{array}$ & $\begin{array}{l}1244 \\
4 *\end{array}$ \\
\hline
\end{tabular}

*Correlation is significant at 0.05 level, ** correlation is significant at 0.01 level.

\section{CONCLUSION}

From this study, I can be inferred from the obtained results that high yield and grain nutrient quality in maize is associated with cropping and high nitrogen levels. So yielding potential in maize production can be associated with relatively high nitrogen supply, crop rotation and together with best agronomical practices such weed control and proper water management supply systems

\section{REFERENCES}

[1] FAO. (2002). Fertilizer and the future. IFA/FAO Agriculture Conference on Global food security and the role of Sustainability Fertilization. Rome, Italy. 16th-20th March, 2003, pp 1-2.in agroeco system. J. Crop Prod. 4, 185-196.

[2] Barnett, V., Payne, R., Steiner, R. (Eds.), 1995. Agricultural Sustainability. Economic, Environmental and Statistical Considerations. Wiley, New York, p. 266

[3] Dolijanović, Ž.,Kovačević, D., Oljača, S., Broćić, Z., \&Simić, M. (2006). The yield grain of winter wheat and maize in continuous cropping, two- and three-crop rotation. Journal of Scientific Agricultural Research, 67, 81-90.
[4] Stranger, T.F., \& Lauer, J.G. (2008). Corn grain yield response to crop rotation and nitrogen over 35 years. Agronomy Journal, 100(3), 643-650.

[5] Riedell, W.E., Pikul, J.L., Jaradat, A.A., \& Schumacher, T.E.(2009). Crop rotation and nitrogen input effects on soil fertility, maize mineral nutrition, yield, and seed composition. Agronomy Journal, 101(4), 870-879.

[6] Karlen, D.L., Varvel, D.G., Bullock, D.G., Cruse, R.M., 1994. Crop rotation for the 21st century. Adv. Agron. 53, $1-45$.

[7] Foster, S.S.D., Cripps, A.C., Smith-Carrington, A., 1982. Nitrate leaching to ground water. Philos. Trans. R. Soc. Lond. 296, 477-489.

[8] Roelofs, J.G.L., Houdijk, A.L.M., 1991. Ecological effects of ammonia. In: Nielson, V.C., Pain, B.F., Hartung, J. (Eds.), Ammonia and Odour Emission from Livestock Production. Elsevier, Barking, UK, pp. 10-16.

[9] Crutzen, P.J., 1981. Atmospheric chemical processes of the oxides of nitrogen, including nitrous oxide. In: Delwiche, J. (Ed.), Denitrification, Nitrification and Nitrous Oxide. Wiley, New York, pp. 17-44.

[10] Silva EC, Ferreira SM, Silva GP, Assis RL \& Guimarães GL (2005)Épocas e formas de aplicação de nitrogênio no milho sob plantiodiretoem solo de cerrado. Revista Brasileira de Ciência doSolo, 29:725-733.

[11] Wozniak, A. (2008). Wpływzrośnicowanego Udziałupszenicyjarej zmianowaniunaindekspowierzchni liści (LAI).Acta Agrophysica, 12(1), 269-276.

[12] Salem, S.A., Ali, A.E., 1979. Effect of nitrogen fertilizer levels and varieties on grain yield and some plant characters of maize (Zea mays L.). Field Crop Abstr. 33 (2), 1035 (Abstr.9881). 